\title{
How to Increase the Internationalization Capacity of Science \& Technology Park Firms: Some Lessons for The Managers'
}

\author{
Sabahattin Tuğrul İMER (https://orcid.org/0000-0003-1596-3048), Gazi Teknopark, Gazi University, Turkey; e- \\ mail: tugrul@crworldinc.com
}

Mustafa Kemal ÖKTEM (https://orcid.org/0000-0002-2040-426X), Department of Political Science and Public Administration, Hacettepe University, Turkey; e-mail: kemalok@hacettepe.edu.tr

Osman Tolga KASKATI (https://orcid.org/0000-0001-8299-2397), BYS Grup Bilişim Sistemleri, Gazi

Teknopark, Gazi University, Turkey; e-mail: tolga.kaskati@bysproje.com

\section{Teknopark Firmalarının Uluslararasılaşma Kapasiteleri Nasıl Artırılır? Yöneticiler için Bazı Çıkarımlar²}

\begin{abstract}
The influence of the increase in internationalization capacity cannot be limited to export only since it also generates indirect impacts stemming through technology transfer, joint project development, trade technology partnerships, training, education and so on. All these activities increase the capabilities of the firms and are expected to have a positive influence on the future productivity, growth and development figures. Within this scope, this paper analyses the impacts of a specific internationalization program which is created by the Turkish Ministry of Trade and run by the Gazi Science and Technology Park (STP) on an ICT cluster of 20 companies for a period of three years.

Keywords

Internationalization, Technoparks, Science \& Technology Parks, Science, Technology, Export, Value-added, Clusters.

JEL Classification Codes : $\quad \mathrm{O} 3, \mathrm{O} 31, \mathrm{O} 32, \mathrm{O} 33, \mathrm{O} 38$.

$\ddot{\mathbf{O} z}$

Uluslararasılaşma kapasitesindeki artış, yalnızca ihracatla sınırlı olmayan teknoloji transferi, ortak proje geliştirme, ticari-teknolojik işbirlikleri, eğitim ve öğrenim gibi faktörlere bağlı birçok dolaylı etkiler oluşturmaktadır. Tüm bu faaliyetler firmaların kapasitelerini arttırmakta ve onların verimlilik, büyüme ve kalkınma rakamları üzerinde ileriye yönelik pozitif etkiler oluşturması beklenmektedir. Bu çerçevede bu makalede T.C. Ticaret Bakanlığı tarafından oluşturmuş ve Gazi Teknopark tarafından üç yıl süreyle 20 firmalık bir bilişim kümesi özelinde yürütülmüş olan hususi bir uluslararasılaşma programının etkileri analiz edilmektedir.
\end{abstract}

Anahtar Sözcükler $\quad$ : Uluslararasılaşma, Teknoparklar, Bilim ve Teknoloji Parkları, Bilim, Teknoloji, İhracat, Katma Değer, Küme.

1 This article is the revised and extended version of the paper presented in " 6 th International Annual Meeting of Sosyoekonomi Society" which was held by Sosyoekonomi Society and CMEE - Center for Market Economics and Entrepreneurship of Hacettepe University, in Warsaw/Poland, on October 24-25, 2019.

2 Bu makale Sosyoekonomi Derneği ile Hacettepe Üniversitesi Piyasa Ekonomisini ve Girişimciliği Gelişstirme Merkezi tarafindan Polonya'nin Varşova şehrinde, 24-25 Ekim 2019 tarihlerinde düzenlenen "Alttncl Uluslararası Sosyoekonomi Derneği Yıllık Buluşması"nda sunulan çalı̧̧manın gözden geçirilmişs ve genişletilmiş halidir. 
İmer, S.T. \& M.K. Öktem \& O.T. Kaskat1 (2021), "How to Increase the Internationalization Capacity of Science \& Technology Park Firms: Some Lessons for The Managers”, Sosyoekonomi, 29(47), 43-58.

\section{Introduction}

This paper sets forth an assessment specifically on the impacts of the internationalization programs which are run by the Science \& Technology Parks (STP's) in Turkey. The STP's, or otherwise named as "Technoparks", are public policy models which are designed within the concept of "Regional Economic Development". In those institutions, many research-based technologies firms are accumulated at the same location to utilize the synergy towards achieving common goals of developing and selling their products \& services. The synergy is expected to be created both through the internal interaction of the companies as well as through their collaboration with outside institutions such as the universities, the industry or research and development (R\&D) labs which are mostly located at geographically close distances.

The outcomes of these policy models ultimately aim to have an impact on the nation's economy through growth and development. This should be possible by increasing the industrial productivity though more value-added creation, with contribution of the improvements in science \& technology. Eventually, the technological advances are expected to be integrated into the manufacturing, agriculture and the service industries.

The science \& technology parks became mostly prominent after the early 1980's. As of today, there are approximately 1,000 science and technology parks around the globe. Including the incubation centres, this number reaches out to around 4,000 (Teknoloji Geliştirme Bölgeleri Derneği [TGBD], 2019).

It follows out that, the main task of STP management companies is to help increase the productive capacity of their tenants, which are mainly R\&D firms, by various means. Foremost important is to own the required facilities as well as the right tools to create a cosy and comfortable working environment for the companies. Principally, the management companies also provide business services such as training and consulting in various fields or run special programs to support the R\&D and commercialization activities of their resident companies. Within this scope, the STP's can assist their tenant firms in finding investors, or they could also introduce them to the appropriate research partners at the universities they are connected with. In some countries, including Turkey, the government also provides special incentives and tax breaks for companies operating at technology parks.

Literally, measuring the success of the STP model is not an easy task, as it depends on wide range of parameters. In regard to impact assessment, there are some studies available. Though they are mostly based on empirical data and relatively limited subjective observations. It turns out that, to lay out a clearer picture, there is a need for more research, which should be based on various data and concrete facts.

In the case of university-industry technology transfer assessment, influential factors for success could be examined based on either document analysis or on the interviews with qualified interviewees, who have been directly involved in technopark projects with industry partners. Barbolla and Corredera's (2009) analysis drives to conclude that, there are some features decisive for success (beyond technological ones) related to the corporate partner's 
İmer, S.T. \& M.K. Öktem \& O.T. Kaskat1 (2021), "How to Increase the Internationalization Capacity of Science \& Technology Park Firms: Some Lessons for The Managers", Sosyoekonomi, 29(47), 43-58.

strategic and functional characteristics. For example, the company's real interest and involvement during the technology transfer process, its capacity to assimilate new knowledge and a confident attitude towards the university research group, are identified to be the key elements for attaining an effective technology transfer. Barbolla and Corredera (2009) refer to Spann, Adams, and Souder (1995) to measure technology transfer effectiveness, through short-term factors (such as number of licenses, requests for help, transfer budgets, etc.) and long term ones (such as cost savings, new commercial sales, new products, royalties, user satisfaction, etc.). They also mention Stock and Tatikonda (2000) to consider some socio-technical features (such as satisfaction) or strategic issues (long-term development of professional competences) while evaluating the effectiveness of technology transfer. Other factors Barbolla and Corredera (2009: 609) propose are; high corporate capacity to put the results into use, good understanding between working teams, use of mature technologies or knowledge, corporate team composed of sufficient qualified professionals, company confidence in project' results and good coordination between working teams.

Bozeman (2000) proposes a technology transfer effectiveness model considering the characteristics of the transferred object (scientific knowledge, physical technology, technology design, process and know-how) and stakeholder features, taking into account the transfer media (open literature, patents, licenses, informal absorption, personal exchange, on-site demonstration, spin-offs...) and also the peculiarities of the demand environment by defining six effectiveness criteria: 'out-the-door', market impact, economic development, political reward, scientific and technical human capital and opportunity cost.

In relation to the diffusion and adoption process of high technology, Albors-Garrigos, Hervas-Oliver and Hidalgo (2009), analyse mechanisms that influence advanced technology transference and marketing, and those features that improve the impact of public programs supporting the adoption of high technology. Adopting a value mapping methodology (a. Short term: partnerships and knowledge sharing; increased and acceleration of R\&D spending; and technical accomplishment (milestones, papers, patents), b. Medium term: commercialization alliances; attraction of capital; new products and processes; and employment growth, c. Long term: changing core competencies; inter- and intra-industry diffusion; societal impacts - health, security, competitiveness; increased national output; and positive public ROI.), they propose a contingent construct that explains how advanced technology is transferred, diffused and adopted by users in a firm. In addition, they refer to the key variables, such as technology complexity; relationships between researchers, developers and final users, as well as market barriers, to be critical for the transference process. They argue that technology absorption by incumbent firms becomes a necessary requirement for its subsequent transfer. Based on experience from the GAME initiative, part of the European Commission IV Research Framework Programme, related to the promotion of microelectronics among Spanish firms, using a representative sample, they found that social impact can be explained by the creation of employment. They emphasize that, the evaluation could also have considered the development of research centres, since some program impacts were detected here. The difficulties associated with measuring the indirect impact of the project, such as the indirect jobs, knowledge transfer to the environment, etc., 
İmer, S.T. \& M.K. Öktem \& O.T. Kaskat1 (2021), "How to Increase the Internationalization Capacity of Science \& Technology Park Firms: Some Lessons for The Managers”, Sosyoekonomi, 29(47), 43-58.

have been evident as well. Further research should be carried out to consider the roles of research centres and outside consultants. $75 \%$ of the projects were carried out by only five centres, some of which exhibited certain attributes of leadership (according to the opinions expressed by the firms). This clearly facilitated the project's success and performance.

Vohora, Wright and Lockett (2004) investigate the development of university spinout companies (USOs), employing a case-based research method, and found that there are two important elements in their development. Each venture must pass through the previous phase in order to progress to the next one; each phase involves an iterative, non-linear process of development, in which there may be a need to revisit some of the earlier decisions and activities. Second, at the interstices between the different phases of development, ventures face "critical junctures" in terms of resources and capabilities to overcome if they are to succeed: opportunity recognition, entrepreneurial commitment, credibility and sustainability.

Bozeman, Rimes and Youtie (2014: 37), review and synthesize the literature on technology transfer effectiveness, focusing particularly on empirical studies of U.S. technology transfer conducted within the last 15 years. They update and extend the "Contingent Effectiveness Model of Technology Transfer" developed by Bozeman (2000) and include the growing interest in social and public value-oriented technology transfer, by asking the key question: Did technology transfer enhance collective good and broad, societally shared values? The theory: "Public interest theory, public value theory". Major advantage and disadvantage: Advantage: Excellent and easily sanctioned criteria for public policy. Disadvantage: Extremely difficult to measure systematically. They categorize studies according to their approaches of measuring effectiveness and another criterion. These studies can be classified as; "Out-the-Door" (Advantage: Does not hold transfer agent accountable for factors that may be beyond control. Disadvantage: Encourages cynicism and focuses on activity rather than outcome), Market Impact (Advantage: Focuses on a key feature of technology transfer. Disadvantage: Ignores important public sector and non-profit transfer; must accommodate market failure issues), Economic Development (Advantage: Appropriate to public sponsorship, focuses on results to taxpayer. Disadvantage: Evaluation almost always requires unrealistic assumptions), Political (Advantage: Realistic. Disadvantage: Does not yield to systematic evaluation), Opportunity Cost (Advantage: Takes into account foregone opportunities, especially alternative uses for scientific and technical resources. Disadvantage: Difficult to measure, entails dealing with the "counterfactual") and "Scientific and Technical Human Capital" (Advantage: Treats technology transfer and technical activity as an overhead investment. Disadvantage: Not easy to equate inputs and outputs).

These factors could be summed up such as capacity, confidence, competence, coordination, capital, cost, commitment, credibility, centres, consultants, and public value. In these respects, it might be useful to approach to this issue by breaking down all the services that the STP management companies provide to their tenants and then put a focus on each of them individually to analyse the real impacts they create from various standpoints. 
Considering limitations of studying those factors and difficulty of measuring their influence, this paper sets forth an assessment, specifically on the impacts of the internationalization programs, which are run by the STP's in Turkey and provides an elaboration on the methodologies, and the business models. Conceptually, "Internationalization" defines all activities related with international collaboration that literally aims to increase the capacities and capabilities of the STP firms in general. Export numbers can be regarded as the only most visible outputs of the internationalization activities.

The figures for Turkey show that the percentage of high technology exports in the whole manufacturing exports, which is an indicator defined by OECD to classify countries with their technology development capacities, has been in the vicinity of two in average between 1996 and 2018 (Konak, 2018). While at the same time, according to a study on STP companies in Turkey, the total export figures in years point to a steady rise between 2001 and 2016 (Cansiz, 2017: 41). Though this can be due to:

- An increase in the number of STP's for that period and

- Accordingly, due to the fact that companies have either established or

- Moved their offices to those institutions through the same selected years.

In fact, there were 2 active STP's and 60 resident companies in 2001 while the same pair of figures went up to 51 and 4,217, respectively in 2016 (Cans1z, 2017: 41). As of June 2019, there are 63 active STP's and 5,328 resident companies in Turkey in total (T.C. Sanayi ve Teknoloji Bakanlığı [STB], 2019). Accordingly, it remains unknown about what portion of that increase in the export pie stems from the rising performance of the individual companies and what portion from the increase in the number of companies only.

From another perspective, the export figures are insufficient alone to evaluate the impact of the internationalization performance. In essence, internationalization cannot be limited only to exporting, since it generates indirect impacts such as stemming through:

- Technology transfer,

- Joint project development,

- Trade and technology partnerships,

- Training or education.

All these activities increase the capabilities of the firms and have a late coming influence on the productivity, growth and development figures. Therefore, it follows out that there is a need for more comprehensive research studies to assess the impact of STP's on the internationalization outcomes of the companies.

In general, the internationalization programs mainly aim to help companies expand their business networks so that they can find potential clients, product \& service providers or trade and research partners. Also, from another perspective, learning from best practices at foreign countries through training or observations is another gain (Yereli, 2016). Literally, 
İmer, S.T. \& M.K. Öktem \& O.T. Kaskat1 (2021), "How to Increase the Internationalization Capacity of Science \& Technology Park Firms: Some Lessons for The Managers”, Sosyoekonomi, 29(47), 43-58.

going international benefits companies both directly and indirectly, and has an undisputable positive impact on their capacity and capabilities in many ways. However, the effectiveness of these programs is important from the cost benefit standpoint, too. While it is important about how the program is designed, equally crucial is how it is run.

In this regard, a research study has been devised to unveil the hidden effects of the internationalization programs run by the STP's and to produce data and information on the impact of internationalization besides export. The outcome of this study gives us the opportunity to elaborate more on the effectiveness of the programs. In same respect, this paper aims to provide practical information as well as suggestions to the policy makers and STP managers in improving the existing methodologies and running better programs.

\section{The Internationalization Program at Gazi Teknopark STP}

The case study has been done in a prominent STP, at "Gazi Teknopark" in Ankara Turkey, to assess the impact of internationalization through an ICT Cluster Community by a pre-post research. Regarding the methodology, a semi-structured questionnaire and a prepost survey has been designed and conducted in a selected sample group of 20 STP resident companies, out of a total of 120 . They are all categorized in the field of information \& communication technology (ICT) and are all a part of a cluster platform which has been actively working to increase the internationalization capacity of their members since 2015 . In order to reach this goal, the cluster platform manager (Gazi Teknopark) has run a special internationalization support program, which was designed and offered by the Ministry of Trade, between 2015 and 2018. The program started with a need analysis that was conducted at the companies at the beginning in order to lay out a three-year road plan, which could be based on some fundamental credentials. This has followed by various training courses on targeted topics such as marketing pitching, international trade transactions and business development, all based on the pre-determined needs of the companies. Then the business delegation visits were planned to the countries, which were selected, based on various criteria in the need assessment study. Each country visit has been regarded as a separate case in which the delegation visits have been diligently planned, 4-5 months in advance by the Gazi STP management, with the aid of a local consulting firm, at the countries to be visited, and also in close coordination with the member companies of the delegation. In accord with all the institutions involved, a continuous work had been executed within the preparation period before the visits. It included long distance calls, meetings, reports, exchange of ideas, feed backs, etc. In particular, the methodology has been on understanding the needs and capacities of each delegation member thoroughly, and then to setting up the business to business (B2B) meetings accordingly. Overall, the program applied by Gazi Teknopark could be described as flexible, custom made, customer based and circumstantial. Within the three years course of the ICT cluster program, four business delegations have been completed; two to the United States, one to Canada and one to Taiwan. 


\section{Research Methodology}

The survey has been conducted to the sample group to analyse the before and after ICT Cluster involvement process of the companies by the differences among the internationalization aspects. Company managers or representatives from 14 ICT Cluster Members have participated to the survey. During the data collection, in-depth interview techniques have been used by the field staff. The structured questionnaire has been used as a data collection form. The questionnaire has been formed by the questions composed by different performance-based aspects such as export, technology transfer, joint project development, trade and technology partnerships, and training or education.

\section{Statistical Analysis}

Regarding statistical analysis, the Wilcoxon signed rank test has been applied as the non-parametric statistical analysis and the results shows that after ICT Cluster involvement of the companies, there is a statistical significance among the internationalization aspect after the ICT Cluster involvement $(\mathrm{P}<=0,05)$ in increasing the "Number of Staff", "Turnover" and "Export Rates" as shown in Table 1 below. These companies in the sample are observed to be relatively better performing, in terms of internationalization, with a set of higher achievement indicators.

Table: 1

Statistical Outputs of the Questions among before and after ICT Cluster Program

\begin{tabular}{|c|c|c|c|c|c|c|}
\hline Survey Questions & Year & $\mathrm{N}$ & Mean \pm STD & Min & Max & $\mathrm{P}$ \\
\hline \multirow{2}{*}{$\begin{array}{l}\text { 1. Has there been an increase / decrease in the number of your sectorial areas } \\
\text { of expertise? }\end{array}$} & 2015 & 14 & $2,36 \pm 1,22$ & 1 & 4 & \multirow{2}{*}{$>0,05$} \\
\hline & 2018 & 14 & $3,07 \pm 2,13$ & 1 & 8 & \\
\hline \multirow{2}{*}{ 2. Has there been an increase / decrease in the number of your staff? } & 2015 & 14 & $21,79 \pm 22,79$ & 2 & 70 & \multirow{2}{*}{0,047} \\
\hline & 2018 & 14 & $32,00 \pm 34,91$ & 2 & 130 & \\
\hline \multirow{2}{*}{ 3. Has there been an increase / decrease in your export volume? } & 2015 & 13 & $136.307,69 \pm 416.578$ & 0 & 1.500 .000 & \multirow{2}{*}{0,043} \\
\hline & 2018 & 13 & $6.294 .851 \pm 15.192 .950$ & 0 & 50.000 .000 & \\
\hline \multirow{2}{*}{$\begin{array}{l}\text { 4. Has there been an increase / decrease in company commercial sales } \\
\text { (turnover)? }\end{array}$} & 2015 & 9 & $5.891 .672 \pm 10.046 .961$ & 233.376 & 30.000 .000 & \multirow{2}{*}{0,012} \\
\hline & 2018 & 9 & $22.084 .920 \pm 32.899 .906$ & 1.200 .000 & 90.000 .000 & \\
\hline \multirow{2}{*}{$\begin{array}{l}5.1 \text { Has the company had an increase / decrease in domestic - overseas } \\
\text { patents? }\end{array}$} & 2015 & 14 & $0,36 \pm 1,08$ & 0 & 4 & \multirow{2}{*}{$>0,05$} \\
\hline & 2018 & 14 & $1,14 \pm 2,32$ & 0 & 8 & \\
\hline \multirow{2}{*}{$\begin{array}{l}\text { 5.2 Has there been an increase / decrease in the Company's domestic and } \\
\text { international utility products? }\end{array}$} & 2015 & 14 & $0,43 \pm 0,85$ & 0 & 2 & \multirow{2}{*}{$>0,05$} \\
\hline & 2018 & 14 & $1,50 \pm 3,08$ & 0 & 11 & \\
\hline
\end{tabular}

Source: Gazi ICT Cluster Survey Results.

As shown in Figure 1 given below, 64,29\% of the participating companies have had meaningful improvements in the company's future vision, productivity, business partnerships and business potential after the ICT Cluster program. 57,14\% of the participating companies have had direct impacts on company's products and services after the ICT Cluster program. 


\section{Figure: 1}

\section{Responses of The Survey Questions Related to Business Activities}
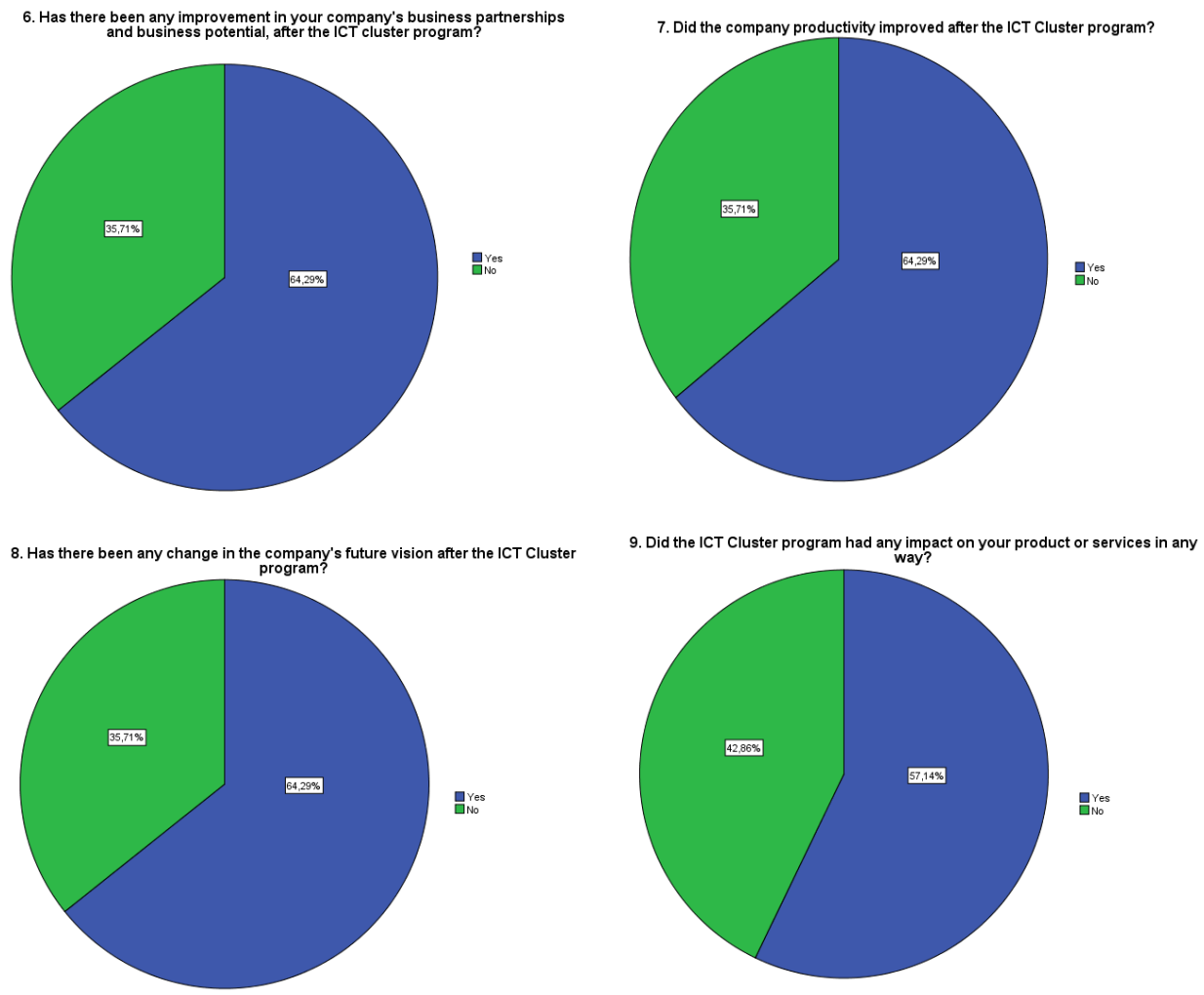

Source: Gazi ICT Cluster Survey Results.

When the policy and technology aspects of the responses are examined, as seen in the Figure 2, it can be said that $64,29 \%$ of the participating companies have had meaningful contributions on the company policies. On the other hand, 64,29\% of the participating companies have declared that technology and research capacity of the human resources have not been affected after the ICT Cluster program. $65,71 \%$ of the companies have created social relationships with the cluster companies and non-cluster entities after the ICT Cluster program. Finally, $64,29 \%$ of the companies have declared that if the ICT Cluster program did not exist, they would have preferred to see a similar internationalization program created. 


\section{Figure: 2}

\section{Responses of the Survey Questions related to Policy / Technology Aspects}
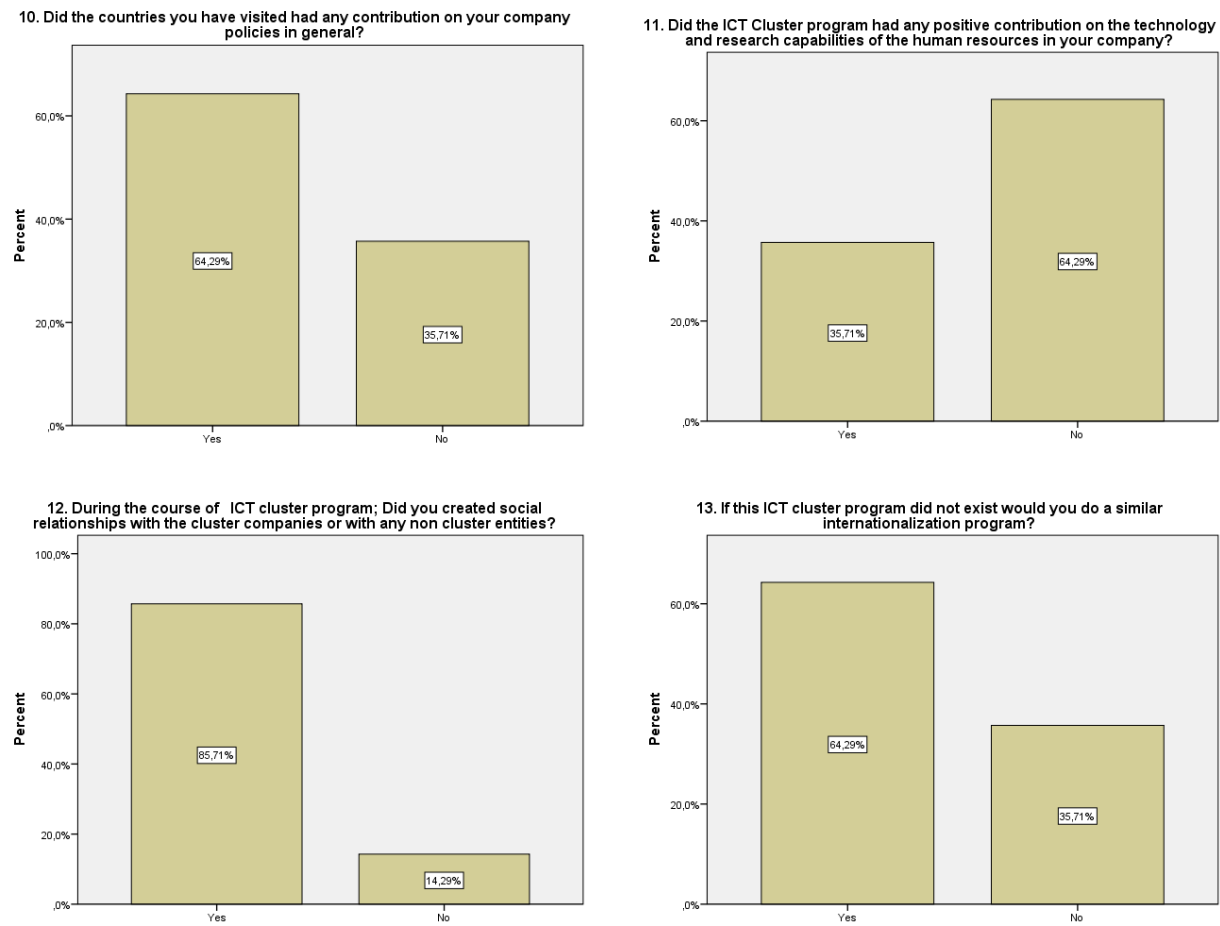

Source: Gazi ICT Cluster Survey Results.

The questions related to the importance levels of some ICT Cluster arguments were asked to the companies. The companies' responses are shown below at Table 2 .

Table: 2

\section{The Importance Level of the ICT Cluster Arguments}

\begin{tabular}{|c|c|c|c|}
\hline $\begin{array}{l}\text { Important Levels of the ICT Cluster Arguments } \\
1=\text { Very important, } 2=\text { Important, } 3=\text { Less important, } 4=\text { Not important }\end{array}$ & Importance Rank & Mean \pm STD & Median \\
\hline 14.1 International Consultant & $4^{\text {th }}$ & $2,50 \pm 1,16$ & 2,00 \\
\hline 14.2 Cooperation with International Companies & $2^{\text {nd }}$ & $2,00 \pm 0,87$ & 2,00 \\
\hline 14.3 Business Programs to reach International Markets & $3^{\text {rd }}$ & $2,07 \pm 0,92$ & 2,00 \\
\hline 14.4 Identification of International Sales Channels & $1^{\text {st }}$ & $1,57 \pm 0,65$ & 1,50 \\
\hline 14.5 Detailed Needs Assessment & $7^{\text {th }}$ & $3,14 \pm 1,23$ & 4,00 \\
\hline 14.6 Support for the R\&D Funds & $5^{\text {th }}$ & $2,71 \pm 1,14$ & 3,00 \\
\hline 14.7 Support for the Internationalization Funds & $6^{\text {th }}$ & $3,14 \pm 0,95$ & 3,00 \\
\hline 14.8 Support for reaching Investor & $8^{\text {th }}$ & $2,93 \pm 0,10$ & 3,00 \\
\hline
\end{tabular}

Source: Gazi ICT Cluster Survey Results.

Based on the responses, the most important argument appears to be the identification and reach out to international sales channels. Moreover, collaboration with an international consultant, cooperation with international companies and conducting a well-designed 
business program are the other prioritized topics for the companies. Nevertheless, the companies think that the support schemes for reaching out to the investors, or to the R\&D and internationalization funds are relatively less important for them ${ }^{3}$.

\section{Discussion of Results}

To analyse the direct and indirect impacts of the internationalization program, which was run by Gazi Teknopark from 2015 through 2018, a questionnaire has been prepared and a poll was conducted on the member companies of the Gazi ICT cluster.

Literally, the direct benefits are analysed in terms of five parameters which are research \& development (R\&D) based domestic sales revenues, R\&D based export revenues, non - R\&D based domestic sales revenues, non- R\&D based export revenues and employment figures. The indirect benefits, on the other hand, are revealed and interpreted based on observations and views of the participants.

In respect with the direct benefits, the result of broad analysis of the previously mentioned five parameters show significant improvements at the end of the three years period from the internationalization perspective in terms of turnover, export rate and employment. Besides, there has been an increase in the number of exporting companies in total; both for the cluster companies and for the whole companies at Gazi Teknopark (Table 3 ). It is notable that the increase in total number of exporting companies between 2015 and 2018 was five and three of them were the member of the ICT cluster.

Table: 3

Number of exporting companies at Gazi ICT cluster and at Gazi Teknopark in Total (2014 -2018)

\begin{tabular}{|c|c|c|}
\hline & \# of Exporting Companies at Gazi Teknopark in total & \# of Exporting Companies at Gazi ICT Cluster at Gazi Teknopark \\
\hline 2014 & 8 & 2 \\
\hline 2015 & 7 & 3 \\
\hline 2016 & 8 & 3 \\
\hline 2017 & 11 & 6 \\
\hline 2018 & 12 & 6 \\
\hline
\end{tabular}

Source: Gazi ICT Cluster Survey Results.

Firstly, it should be stated that, three-year period is too short to see the immediate direct impacts on the sales \& employment figures. A sustainable upward trend is yet to be acknowledged in the due course. Regarding the indirect benefits, however, very positive improvements were reported by the companies in terms of business management, business model improvement, market exposure, marketing perspectives, enlargement of vision, foreign market expansion and joint project development capacity.

As an example, for a tangible outcome, 3-4 companies have come together to open up a foreign office abroad for foreign market exposure and international business development. These companies have also started to develop joint projects.

3 A broad analysis for this issue, see Fazlıoğlu et al., 2019. 
Other example is about a collective product development project which resulted with a concrete output. The product is ready to go and is in the commercialization phase at this point. In this context, three companies of the "Gazi ICT Cluster", who had not known each other well enough, joined their forces and started collaborating on a common ground. The idea of product development came out as a result of some of the pitching sessions attended during the delegation visits.

Another example to concrete outcome is, about the effort of one Gazi ICT member companies for a joint investment transaction, with one foreign company, they had met during the delegation visits.

It can be argued that if let alone, none of the occasions in those examples would have come true. The improvement in vision \& networking could be regarded among the notable merits in contributing to these happenings.

Moreover, with further analysis of the sales figures, it is notable that, there is an upward trend in the R\&D domestic exports during the program, between 2015 and 2018 (Figure 3). Even by excluding the very big disproportionate jump in the figure for 2017, due to a massive project sale of one cluster company in that particular year, the steady upward trend is still notable. This picture is also in accord with the outcome of our statistical analysis, which is based on real data derived from the cluster companies, during the in-debt interview. Accordingly, although the period is too short to make a concrete statement on the continuously souring export trend yet, it can be argued that, the indirect impacts of the cluster program may have had a positive contribution on the performance of the cluster companies.

Figure: 3

R\&D based Total Annual Exports (US\$) of Gazi ICT Cluster Companies (2015-2018)

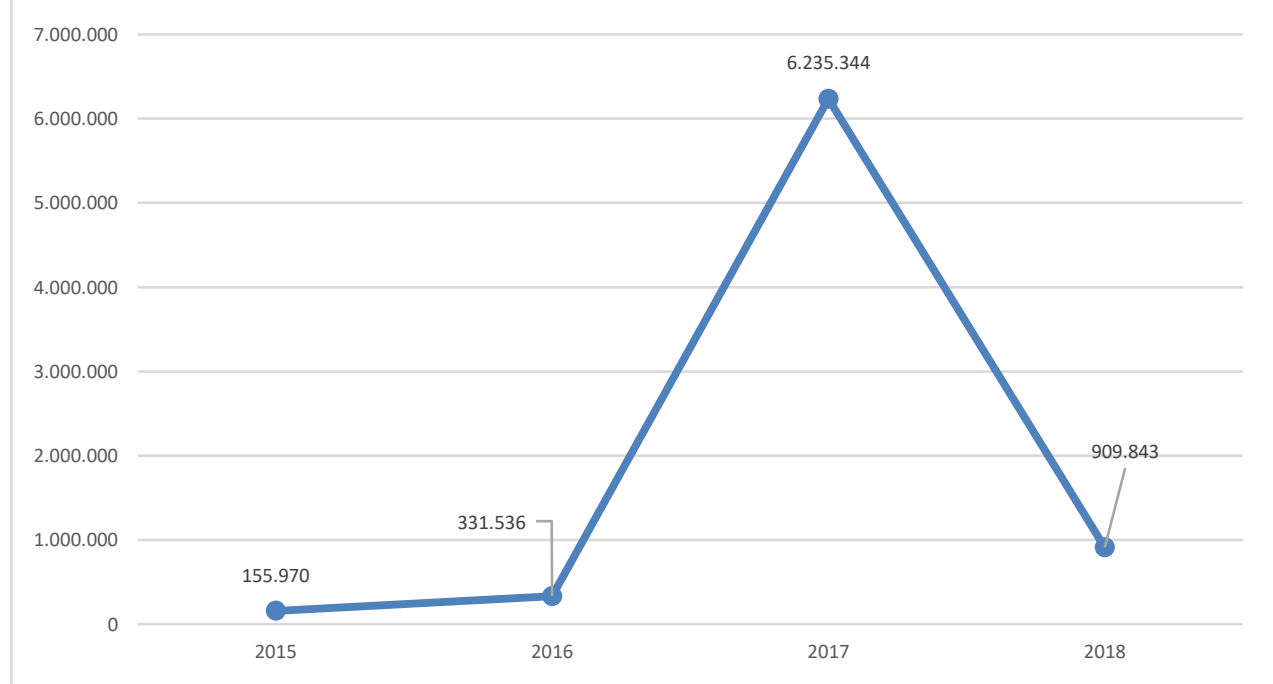

Source: Gazi Technopark and Gazi ICT Cluster Survey Results. 
It is also an important fact that the sales of more value- added products and services is more difficult to realize than that of the less value- added ones. This may depend on many issues such as capacity, capability, reliability, marketing, funding and branding issues. Nevertheless, the upward trend in R\&D based exports, rather than the non-R\&D based exports (Figure 4) is more desired from the perspective of the STP mission. It is evident that, one target of the STP management is to support the resident companies for expanding their volume of R\&D based sales.

\section{Figure: 4}

\section{Non-R\&D based Total Annual Exports (US\$) of Gazi ICT Cluster Companies (2015 -2018)}

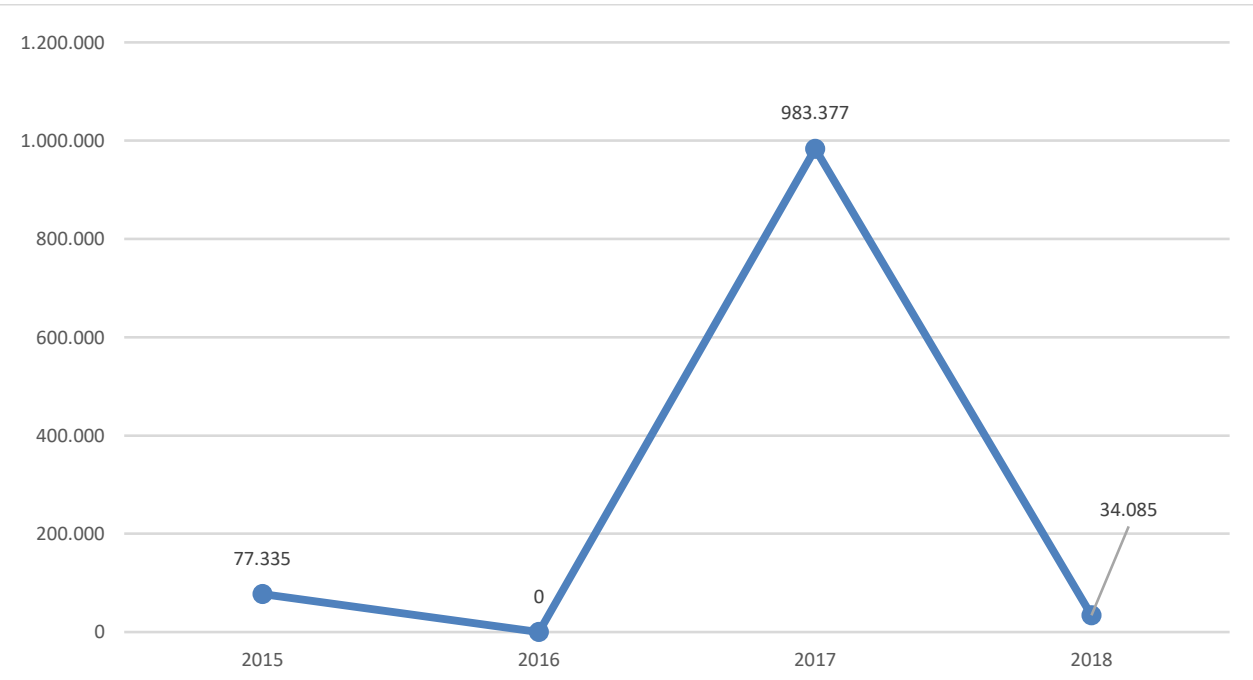

Source: Gazi Technopark and Gazi ICT Cluster Survey Results.

The R\&D and non- R\&D based domestic sales show a fluctuating but a steady trend during the period of 2015 and 2018 (Figure 5 and Figure 6). The reason for this drift can be due to the downturn of the Turkish economy between 2016 and 2018, which had a negative impact on the capacities, \& capabilities of the Turkish companies in general. 
İmer, S.T. \& M.K. Öktem \& O.T. Kaskat1 (2021), "How to Increase the Internationalization Capacity of Science \& Technology Park Firms: Some Lessons for The Managers", Sosyoekonomi, 29(47), 43-58.

Figure: 5

R\&D based Total Annual Domestic Sales (US\$) of Gazi ICT Cluster Companies (2015 -2018)

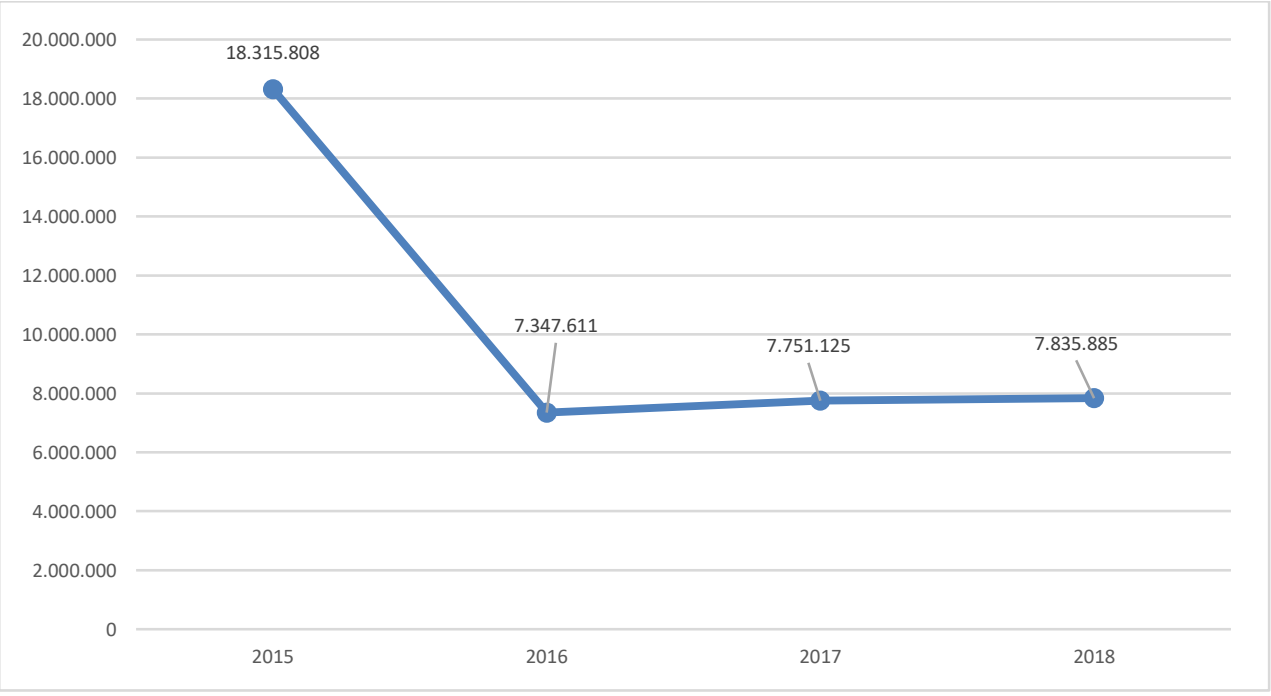

Source: Gazi Technopark and Gazi ICT Cluster Survey Results.

Figure: 6

Non-R\&D based Total Annual Domestic Sales (US\$) of Gazi ICT Cluster Companies (2015 -2018)

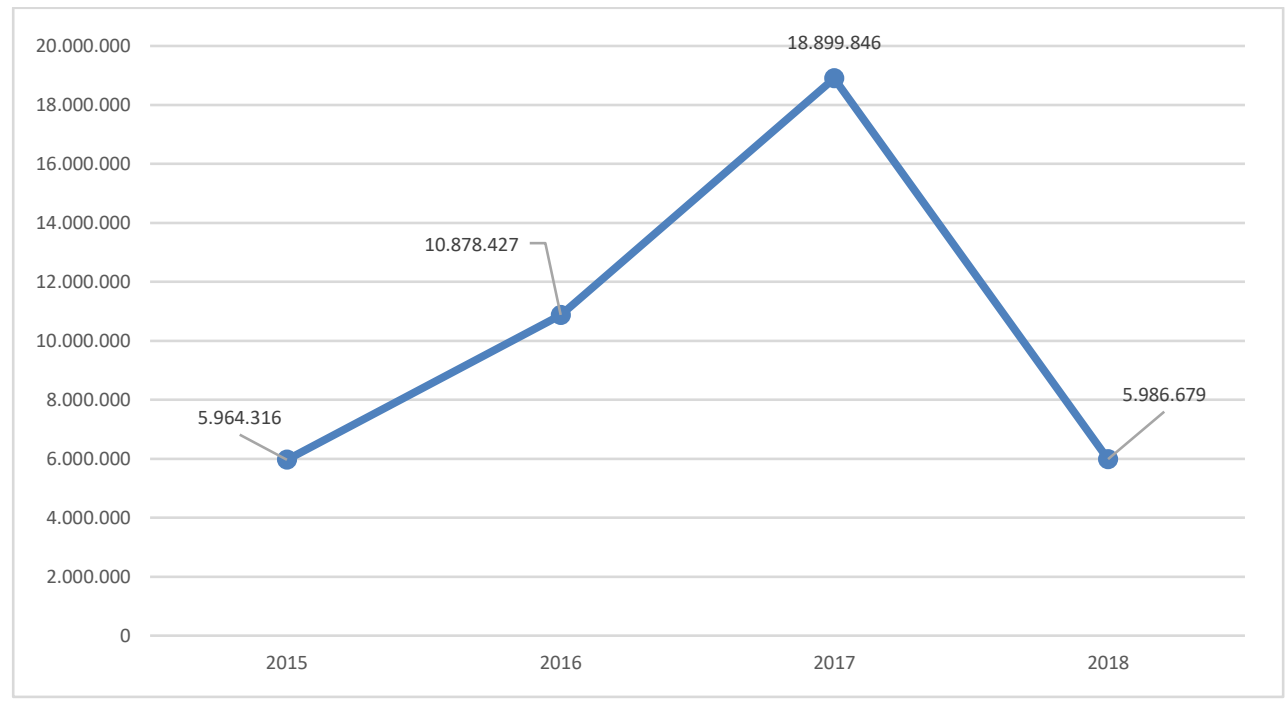

Source: Gazi Technopark and Gazi ICT Cluster Survey Results. 
From the employment perspective, there is an obvious and remarkable increase in the numbers between 2015 and 2018 (Figure 7). As compared with the average unemployment rate in Turkey for the same period, this tendency points to some success for the Gazi STP ICT cluster companies. The spike in employment figures can be attributed to many reasons. Overall, the impact of both R\&D based exports and sales could be evident. In fact, one can expect a positive correlation between increased R\&D based sales (domestic \& export) and rising employment. Because, value added revenue generation supposedly creates more profit for the companies and some proportion of this might supposedly be reinvested into human capital. It can also be argued that, the steady trend in domestic sales for both R\&D and nonR\&D figures did not put any pressure on the companies to lay off the existing staff.

\section{Figure: 7}

\section{Total Annual Employment at Gazi ICT Cluster Companies (2015 -2018)}

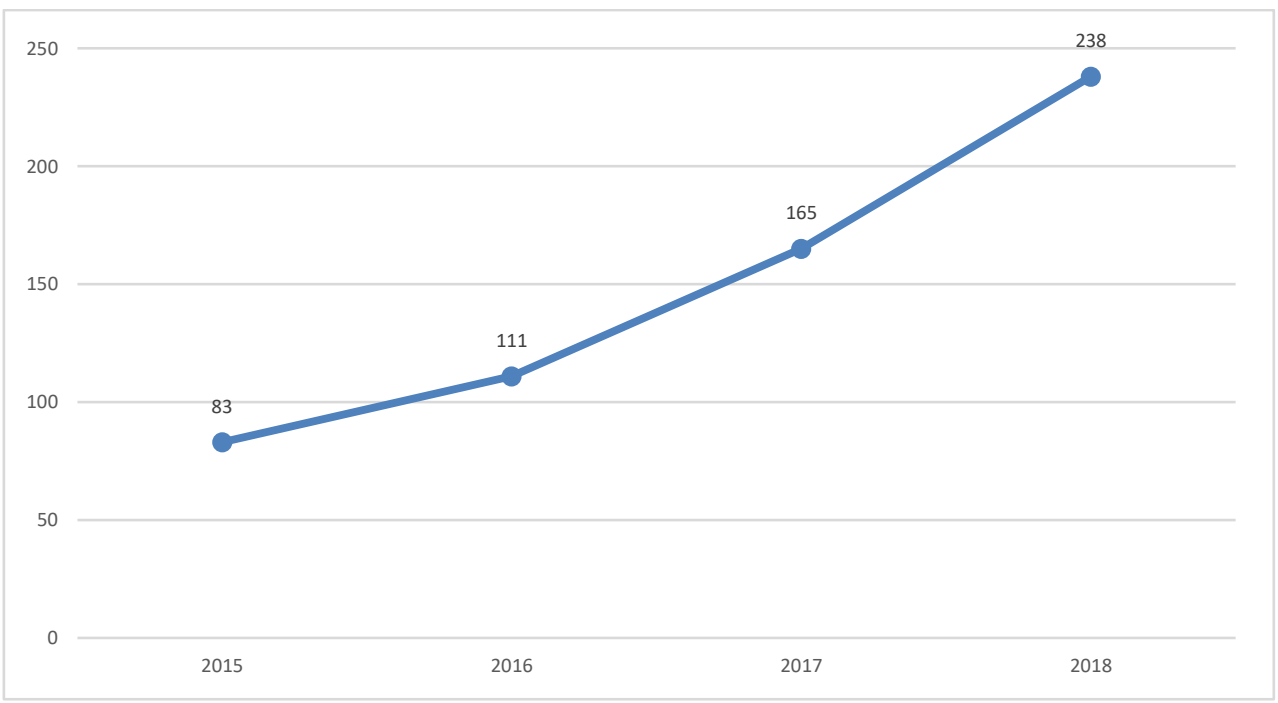

Source: Gazi Technopark and Gazi ICT Cluster Survey Results.

\section{Conclusion}

Internationalization is a comprehensive subject, which harbours a wide array of extensive opportunities for the Science \& Technology Park (STP) companies. They can utilize those openings to achieve better value-added outcomes.

This paper aims to give a broad perspective on the impact of the particular internationalization program which is created by the Ministry of Trade (Ministry of Economy by that time) of Turkey. The assessment analysis has been done in a narrower scope, on one cluster only, and with limited number of companies. It turns out that, there is a need for a much wider scope analysis based on information and data on a national scale. Also, the period of three years is too short of a time to deliver significant results, particularly in respect with the impact on the sales and employment figures. However, besides the 
improvement in employment and R\&D based sales trend within the period of 2015-2018, the indirect benefits are detected to be immediate and tangible. Moreover, it is a historically proven fact for many country cases that, technology and knowledge has been spilled over through observations, collaborations, training and education. Afterwards, technologies and methodologies have been adopted and further developed. This fact has been even reflected into the Turkish Public Personnel Law of 1965, which is still in effect today. At multiple sub legislations of this law, there are clauses which are mentioning the procedures, rights and responsibilities of civil servants who are to be sent to foreign countries to stay for certain periods for, the aim of increasing their level of knowledge (Devlet Memurları Kanunu, 1965).

In case of Gazi ICT cluster, it can be argued that, the internationalization program has produced positive results. In general, field research results from our specific-sample group indicate to improvement in skills and vision through learning and meeting. However, the imminent impact on direct sales remains limited. Nonetheless, indirect benefit has been reported that affected opening up policies of the companies, which changed their strategy or increased their capacity. Those outcomes were reported to bring retarded positive results on their sales figures, domestically and internationally. Another benefit was reported on expansion through networking, which enabled companies to partner up with other foreign companies in marketing and sales. It is also very crucial to note that the way the program has been run, matters a lot. That means;

- A flexible program that takes the need into consideration of each company within a cluster,

- Thoroughly preparation time before trips at an average of 4 months,

- Working with a local consultant.

can be considered among the key factors for the achievement of fruitful outcomes from such internationalization programs, based on the experience from the "Gazi ICT" Cluster case.

On the other hand, "only trade show targeted trips" do not seem to balance the costbenefit balance, while the program should be built around with business to business (B2B) meetings in order to ramp up the level of exploitation.

Nevertheless, for our sample companies, besides the rising export figures, our research results unveiled some indirect positive impacts regarding the internationalization capacity of some firms, which are either not yet reflected to the export numbers or had an unrevealed impact, which is integrated in their productivity or domestic sales. This research findings also provided hints about the pros and cons of the existing internationalization programs. In general, this article is expected to give an outline to the policy makers at the macro scale, and a guideline to the internationalization program managers at the micro scale. Regarding the macro scale assessment, the impact of this program has been evaluated from the standpoint of economic growth and development as well as public interest and social benefits. Nonetheless, as a tangible outcome at the micro level, an optimized 
İmer, S.T. \& M.K. Öktem \& O.T. Kaskatı (2021), "How to Increase the Internationalization Capacity of Science \& Technology Park Firms: Some Lessons for The Managers”, Sosyoekonomi, 29(47), 43-58.

internationalization program model, based on the impact evaluation of the real case Gazi ICT cluster internationalization program, has been laid out.

Therefore, in general, it can be argued that, the impact of the internationalization programs yields positive results, regardless. However, when taking the cost - benefit approach into consideration, the cost of the program born by the government, should be assessed in terms of the total positive impacts it creates from a wider scope. Both the direct and indirect benefits should be integrated into the equation. To achieve more proper results, a much wider group of clusters should be analysed within a longer time span.

\section{References}

Albors, J. \& J.L. Hervas-Oliver \& A. Hidalgo (2009), “Analysing high technology adoption and impact within public supported high tech programs: An empirical case", Journal of High Technology Management Research, 20(2), 153-168.

Barbolla, A.M.B. \& J.R.C. Corredera (2009), "Critical Factors for Success in University-Industry Research Projects”, Technology Analysis \& Strategic Management, 21(5), 599-616.

Bozeman, B. \& H. Rimes \& J. Youtie (2014), "The evolving state-of-the-art in technology transfer research: Revisiting the contingent effectiveness model", Research Policy, 44(1), 34-49.

Bozeman, B. (2000), “Technology Transfer and Public Policy: A Review of Research and Theory", Research Policy, 29, 627-55.

Cansız, M. (2017), 2023 'e Doğru Türkiye Teknoparkları, T.C. Kalkınma Bakanlı̆̆ı, Sosyal Sektörler ve Koordinasyon Genel Müdürlüğü.

Fazlığlu, B. \& B. Dalgıç \& A.B. Yereli (2019), “The Effect of Innovation on Productivity: Evidence from Turkish Manufacturing Firms”, Industry \& Innovation, 26(4), 439-460.

Konak, A. (2018), "Yüksek Teknoloji İçeren Urun İhracatının İhracat Hacmi ve Ekonomik Büyüme Üzerine Etkisi; Seçilmiş OECD Ülkeleri ve Türkiye Örneği”, Yönetim, Ekonomi, Edebiyat, İslami ve Politik Bilimler Dergisi, 3(2), 56-80.

Stock, G.N. \& M.V. Tatikonda (2000), “A typology of project-level technology transfer processes”, Journal of Operations Management, 18, 719-37.

T.C. Sanayi ve Teknoloji Bakanlığı [STB] (2019), Teknoloji Geliştirme Bölgeleri, Ankara, $<$ https://btgm.sanayi.gov.tr/Handlers/DokumanGetHandler.ashx?dokumanId=d2f2bda44fab-4b36-8352-e997d96dae74>, 30.07.2019.

Teknoloji Geliştirme Bölgeleri Derneği [TGBD] (2019), Dünyadaki Teknoparklar, Ankara, <https://www.tgbd.org.tr/dunyadaki-teknoparklar-icerik-34>, 30.07.2019.

Vohora, A. \& M. Wright \& A. Lockett (2004), "Critical junctures in the development of university high-tech spinout companies”, Research Policy, 33, 147-175.

Yereli, A.B. (2016), “Türk Dünyasında Teknolojik İşbirliğinin Önemi ve Teknoparklar”, Yeni Türkiye, Bilim ve Teknoloji Özel Sayısı II, Temmuz-Aralık, (89), 409-416. 